NBER WORKING PAPER SERIES

THE INTERNATIONAL ROLE OF THE DOLLAR AND TRADE BALANCE ADJUSTMENT

\author{
Linda Goldberg \\ Cédric Tille \\ Working Paper 12495 \\ http://www.nber.org/papers/w12495
}

\author{
NATIONAL BUREAU OF ECONOMIC RESEARCH \\ 1050 Massachusetts Avenue \\ Cambridge, MA 02138 \\ August 2006
}

We thank Joseph Gagnon, Peter Kenen, and participants of the Group of Thirty for valuable comments. The views expressed in this article are those of the authors and do not necessarily reflect the position of the Federal Reserve Bank of New York or the Federal Reserve System. The views expressed herein are those of the author(s) and do not necessarily reflect the views of the National Bureau of Economic Research.

@2006 by Linda Goldberg and Cédric Tille. All rights reserved. Short sections of text, not to exceed two paragraphs, may be quoted without explicit permission provided that full credit, including $\odot$ notice, is given to the source. 
The International Role of the Dollar and Trade Balance Adjustment

Linda Goldberg and Cédric Tille

NBER Working Paper No. 12495

August 2006

JEL No. F1, F3, F4

\begin{abstract}
$\underline{\text { ABSTRACT }}$
The pattern of international trade adjustment is affected by the continuing international role of the dollar and related evidence on exchange rate pass-through into prices. This paper argues that a depreciation of the dollar would have asymmetric effects on flows between the United States and its trading partners. With low exchange rate pass-through to U.S. import prices and high exchange rate pass-through to the local prices of countries consuming U.S. exports, the effect of dollar depreciation on real trade flows is dominated by an adjustment in U.S. export quantities, which increase as U.S. goods become cheaper in the rest of the world. Real U.S. imports are affected less because U.S. prices are more insulated from exchange rate movements pass-through is low and dollar invoicing is high. In relation to prices, the effects on the U.S. terms of trade are limited: U.S. exporters earn the same amount of dollars for each unit shipped abroad, and U.S. consumers do not encounter more expensive imports. Movements in dollar exchange rates also affect the international trade transactions of countries invoicing some of their trade in dollars, even when these countries are not transacting directly with the United States.
\end{abstract}

\author{
Linda Goldberg \\ Research Department, 3rd Floor \\ Federal Reserve Bank-New York \\ 33 Liberty Street \\ New York, NY 10045 \\ and NBER \\ linda.goldberg@ny.frb.org \\ Cédric Tille \\ International Research Function \\ Federal Reserve Bank of New York \\ 33 Liberty Street \\ New York, NY 10045-1003 \\ cedric.tille@ny.frb.org
}




\title{
The International Role of the Dollar and Trade Balance Adjustment
}

\author{
Linda Goldberg* \\ Federal Reserve Bank of New York and NBER \\ Cédric Tille \\ Federal Reserve Bank of New York
}

May 8, 2006

\section{Introduction.}

A number of things must happen before exchange rate changes lead to trade balance adjustments. First, the exchange rate change must lead to changes in the border prices of goods imported by the destination market. Next, the change in border prices must lead to a change in the price of goods charged to consumers. Finally, the consumer must react to the relative price of import goods, substituting away from imports if they have become more expensive, or increasing demand for imports if they have become relatively cheap. If the exporters adjust their own profit margins to insulate foreign prices from exchange rate fluctuations, nominal trade balance implications arise purely due to revenue effects of exchange rates on existing quantities of goods traded.

In the current debate over global imbalances, contributors differ in their views of how much trade balance adjustment is achievable through adjustments in global aggregate demand versus specifically through relative prices, as in Feldstein (2006), who advocates substantial depreciation of the U.S. dollar as a key adjustment instrument. Most of these studies share the key premise that exchange rates play a role in influencing the relative prices of domestic and foreign goods, so that a U.S. dollar depreciation reduces U.S. imports and spurs its exports to foreign markets. ${ }^{1}$

Whether or not the demand for traded goods is sensitive to exchange rates has long been recognized as a central issue in international transmission and adjustment, and was the theme of the first Occasional Paper published by The Group of Thirty, by Kenen and Pack (1980).

\footnotetext{
${ }^{*}$ We thank Joseph Gagnon and Peter Kenen for valuable comments. The views expressed in this article are those of the authors and do not necessarily reflect the position of the Federal Reserve Bank of New York or the Federal Reserve System.

${ }^{1}$ A recent NBER volume nicely overviews some alternative positions in this debate. See G-7 Current Account Imbalances: Sustainability and Adjustment, edited by Richard Clarida (forthcoming, NBER and University of Chicago Press).
} 
Immediately after the Bretton-Woods system ended, one concern was whether real exchange rates were truly flexible in a way that supported real adjustments. At that time, the debate focussed on the point that if both nominal exchange rates and domestic prices were flexible, real exchange rates would not move enough to correct external imbalances. As a consequence, trade adjustment would need to occur solely through changes in the aggregate demand of trading partners and nominal exchange rate movements would be ineffective in addressing real imbalances. Kenen and Pack (1980), however, were early proponents of the view that changes in nominal exchange rates would induce relative price adjustments, and would help economies adjust their international imbalances.

Now, more than twenty-five years later, the strength of the exchange rate instrument in trade-balance adjustment is again hotly debated. We argue that the debate needs to pay heed to the special international role of the dollar as a vehicle currency and as a unit of account. The theory and evidence on the use of dollars and euros as invoicing currencies in international trade transactions are consistent with evidence on low pass through of exchange rate movements into the import prices of the United States and the higher pass through into import prices of other countries. A consequence of this distinction in exchange-rate pass through into prices is that the trade balance effects of exchange rate depreciation can be dramatically different for the United States compared with other countries. A U.S. dollar depreciation is expected to lead to little change in U.S. demand for imports while leading to potentially large increases in world demand for U.S. exports, which will have become cheaper in foreign currency terms. The competitive effects of dollar depreciation are strongest for U.S. exporters and foreign producers competing with these goods. While the U.S. trade balance will respond to changes in the value of the dollar, the special international role of the dollar and the related low degree of exchange-rate pass through into U.S. import prices will lead the trade balance response to be primarily through increased quantities of U.S. exports.

Section II begins by reviewing the theory of currency selection in invoicing international trade transactions. Our recent contributions to this area build on the rich history of thought on this topic, from the 1960s through the present. ${ }^{2}$ These contributions advanced a range of explanations for why a currency becomes a vehicle for pricing and international transactions, including transaction costs in foreign exchange markets, inertia and market depth, industry

\footnotetext{
${ }^{2}$ Kenen (1983) overviews the early evidence and arguments in Group of Thirty Occasional Paper no. 13.
} 
structure, and macroeconomic volatility. We then provide evidence on the extent to which exporters use dollars and euros as invoicing currencies. The U.S. dollar and the euro are the main currencies used for transactions in global markets. The dollar is dominant because of the large weight of the United States and dollar bloc countries in international transactions, and because of the importance of the dollar in invoicing trades of commodities and other homogeneous goods. These findings are consistent with survey results reported in the recent Conference Board and Group of Thirty project on “Do Exchange Rates Matter?” (2005). That paper observed that "one of the most interesting results of the survey - one with significant policy implications - is the extent to which global businesses manage exchange rate risk by reducing the number of currencies that account for the majority of foreign exchange exposure. Global companies may produce in dozens of countries and may sell in a hundred or more, but two-thirds of the companies indicate that five currencies or less account for all of their foreign exchange exposure." (page 8). We argue that this dominant role for the dollar in international transactions is likely to persist.

In Section III we discuss exchange rate pass through into the prices of goods as they enter a country, and reasons why this pass-through is typically incomplete. It is now wellestablished that exchange-rate pass through into import prices is incomplete, variable across types of goods, and lower for the United States than for other industrialized countries. The special role of the U.S. dollar as a key vehicle currency in international transactions helps to insulate U.S. prices from exchange rate fluctuations. While this insulation is immediately apparent in the dollar prices of U.S. imports, additional damping of exchange rate effects on prices occurs by the time the imported good reaches consumers. The damped effect on consumption prices of imported goods occurs because local country content arising from the distribution sector dilutes the share of the total product cost that is attributable to import content. Moreover, distributors may actively absorb some exchange rate movements within their own profit margins.

In Section IV we examine how exchange rate movements affect the trade balance. When consumption prices of imported goods are responsive to exchange rates expenditure-switching occurs when a home currency depreciation raises the price of foreign goods sold in home markets relative to the prices of local substitutes. A real trade surplus develops as foreign consumers increase their demand for home exports and home consumers reduce quantities 
imported of the foreign good. This real surplus does not necessarily translate to a nominal surplus in home currency terms, as the higher price of imports (a worsening of the terms of trade) tends to increase the dollar cost of imports. Our twist to this well-known adjustment story hinges on the special role of the dollar as an invoicing currency in international trade, and the related observation that exchange-rate pass through into import prices is lower for the United States than for other countries. This feature generates an asymmetry across countries in trade balance effects of exchange rates. When import prices are not affected much by exchange rate movements, which is the case when exchange-rate pass through into prices is very low, expenditure-switching does not occur in the home market. A domestic currency depreciation does not lead to much of a decline in import quantities. At the same time a depreciation of the dollar raises quantities of U.S. exports through the expenditure effect, as foreign consumers substitute away from other suppliers and toward U.S. goods. The U.S. dollar depreciation reduces the trade deficit of the United States, but mainly by stimulating U.S. exports. As U.S. import prices do not increase substantially and its exports are priced in dollar terms, the United States is shielded from a depreciation of its terms of trade.

In addition to affecting trade adjustment between the United States and the rest of the world, the dollar's prominence in invoicing international trade transactions even affects the trade balances of countries engaging in transactions that do not involve the United States. The pattern of consequences depends on the extent to which different countries use dollar for invoicing and pricing their bilateral transactions. U.S. dollar depreciations can raise the competitiveness of products invoiced in dollars elsewhere, both relative to produces invoicing in other currencies, and relative to their domestic goods.

We conclude this paper with a discussion of the policy implications of our analysis. Some of the lessons drawn from recent research were already anticipated twenty-five years ago, in early seminal work on this topic, including the first Occasional Paper written for the Group of Thirty by Kenen and Pack (1980). They had concluded, "a change in the nominal exchange rate does produce a change in the real exchange rate. The latter will be smaller than the former and may be very small for small open economies, but it need not be trivial or transitory. Trade flows are moderately sensitive to a change in the real exchange rate; price elasticities are not negligible. Taken together, these conclusions say that a depreciation of one country's currency will increase its exports and reduce its imports, though long lags may be involved." Now, with 
the advantage of considerably more data and decades of development of theoretical tools, this theme from the early literature is validated. We add the key observations that the special role of the U.S. dollar in invoicing international trade transactions, and evidence on partial and asymmetric exchange-rate pass through into import prices across countries, imply that real trade adjustment may be asymmetric. The U.S. might not adjust demand for imported goods when the dollar depreciates. By contrast, the dollar depreciation increases the competitiveness of U.S. goods in foreign markets, so that real quantities adjusted would be limited to exports of U.S. products and the foreign sales that these exports displace.

\section{Invoice Currencies in International Trade Transactions}

The theoretical determinants of invoicing-currency choice include arguments that emphasize the roles of transaction costs, industry structure, and macroeconomic volatility. Here we briefly review the key theoretical contributions before turning to the empirical evidence on invoicing, and the key roles currently played by the dollar and the euro.

Determinants of trade invoicing.

Early contributions to this literature focused on the role of currencies as mediums of exchange. The importance of using currencies with low transaction costs in foreign exchange markets, still discussed in current analysis, was stressed by Swoboda (1968, 1969). Such low costs could, for instance, reflect a high degree of liquidity in the foreign exchange markets for the currencies in question (Portes and Rey, 1998). Rey (2001) argued that there are "thick market externalities" associated with a currency's large presence in global international trade, which yields low transaction costs of exchange. In theoretical work by Devereux and Shi (2005), a vehicle currency through which all trading takes place can emerge as a way to minimize trading-post setup costs.

Another argument for invoice currency selection centers on industry characteristics, and in particular stresses that single currencies may be selected for use in the pricing and invoicing of homogeneous goods. McKinnon (1979) argued that industries where goods are homogeneous and traded in specialized markets are likely to have transactions invoiced in a single low transaction cost currency. Krugman (1980) pointed to the presence of inertia in the choice of currency used for this pricing and discussed the disincentives against deviating from the industry 
norms. Once a currency acquires prominence, perhaps because of low transaction costs, it may keep this role even if another currency with similarly low costs emerges.

A third line of argument emphasizes that macroeconomic policy and volatility could influence the emergence of vehicle currencies. Firms have an incentive to invoice their trade in the currency of a country where the volatility of shocks, such as those arising from monetary aggregates, is moderate, as this will ceteris paribus minimize the fluctuations in the exchange rates associated with the currency in questions (Giovannini 1988, Wilander 2006).

Recent research contributions by Bacchetta and van Wincoop (2005), Devereux, Engel and Storegaard (2004), and Goldberg and Tille (2005) take these alternative arguments further. Bacchetta and van Wincoop (2005) stress the role of structural features of economies, such as price elasticities of demand and the convexity of production costs. They also point to the presence of a herding effect: if several currencies are available for invoicing, the exporter has an incentive to invoice in the currency used by the majority of her competitors, as doing so limits the volatility of output and marginal costs. Devereux, Engel and Storegaard (2004) focus on the role for monetary fluctuations in the invoicing decision, showing that exporters choose to set their prices in the currency of the country where monetary shocks are the least volatile.

The research by Goldberg and Tille (2005) expands on the multi-currency analysis of Bacchetta and van Wincoop (2005) and contrasts the role of the herding motive with other motives, such as the desire to hedge macroeconomic volatility. Herding considerations are found to play a sizable role in choosing the single currency to be used for invoicing international transactions, and are expected to be the dominant consideration for industries where goods are more homogenous. Invoicing of transactions for highly differentiated goods, like manufactured products, is likely to be more evenly spread across the various currencies and may be more responsive to macro-economic volatility. If macroeconomic volatility is an input into invoice currency decisions, it would enter because of patterns of correlations between exchange rates and marginal costs, as opposed to the volatility of the exchange rate per se.

Our model also confirms the findings in the early literature that a currency is more likely to be used in invoicing if it has low transaction costs. While herding means that exporters will use a common currency, it does not indicate which currency should play that role. Introducing transaction costs complements the analysis, as we can expect exporters to coordinate their choice 
of invoicing currency on the currency with low transaction costs. As in the Krugman (1980) inertia arguments, this mechanism can feed on itself if the low costs are driven by the liquidity of the foreign exchange market. Such a virtuous cycle mechanism can explain why a particular currency can persist as a vehicle currency for a substantial period.

The evidence on currency invoicing in international trade

Goldberg and Tille (2005), the follow-up study by Kamps (2005), and the ECB (2005) report provide extensive cross-country evidence on the currency invoicing of international trade transactions. ${ }^{3}$ These analyses show that both the U.S. dollar and the euro are extensively used in international trade transactions, with the dollar still the dominant currency. Across countries, "Grassman's Law" still seems to hold, i.e. countries tend more extensively use their own currency on export invoicing than on import invoicing (Grassman 1973).

Table 1, using data reported in these studies, shows the use of dollars in invoicing country exports and imports at the latest year for which data are available across countries. International trade transactions between other countries and the United States are primarily invoiced in U.S. dollars. More than 99 percent of U.S. exports and 92 percent of U.S. imports were invoiced in dollars in early 2003. Those countries using their own currencies on part of their sales to the United States are the United Kingdom, Japan, and some euro area countries.

Approximately one third of the exports of most euro area countries (to countries outside of the euro area) are invoiced in dollars, with nearly 40 percent of euro area imports invoiced in dollars. The U.S. dollar is used intensively in the United Kingdom's international trade transactions, on 26 percent of U.K. total exports and 37 percent of U.K. imports. The EU acceding and accession countries are mixed in the extent to which dollars are used in invoicing their international trade transactions, with dollar shares in invoicing international trade often lower for these countries than for euro-area countries. By contrast, the dollar remains a dominant currency in the invoicing of both exports and imports by countries outside of Europe. Both Korea and Thailand use the dollar in invoicing more than 80 percent of their export and import

\footnotetext{
${ }^{3}$ Details on the currency invoicing of international trade transactions previously were scarce. Some recent but discrete facts focusing on individual countries or regions, as in Swedish invoicing by Friberg (1998) and Wilander (2006), Canadian invoicing by Donnenfeld and Haug (2003), and Japan by Oi, Otani, and Shirota (2004). Evidence for euro-area and accession countries, in part triggered by the advent of the euro and efforts to track its adoption in goods markets and financial markets (European Central Bank 2002). See also Goldberg (forthcoming) on euro-area accession countries.
} 
transactions. For Japan, Australia, and Malaysia, the dollar is used in substantially more than 50 percent of trade transactions.

Table 1: U.S. Dollar and Euro Use in the Export and Import Invoicing of 24 Countries

\begin{tabular}{|c|c|c|c|c|c|}
\hline & & \multicolumn{2}{|c|}{ Export Invoicing } & \multicolumn{2}{|c|}{ Import Invoicing } \\
\hline & Date & Dollar Share & Euro Share & Dollar Share & Euro Share \\
\hline United States & 2003 & 99.8 & & 92.8 & \\
\hline \multicolumn{6}{|l|}{ Asia } \\
\hline Japan & 2003 & 48.0 & 9.6 & 68.7 & 4.5 \\
\hline Korea & 2004 & 83.2 & 7.4 & 79.6 & 5.4 \\
\hline Malaysia & 2000 & 90.0 & -- & 90.0 & -- \\
\hline Thailand & 2003 & 84.4 & 2.7 & 76.0 & 4.3 \\
\hline Australia & 2004 & 69.6 & 1.3 & 50.5 & 9.0 \\
\hline \multicolumn{6}{|l|}{ Euro-Area } \\
\hline Belgium $^{\mathrm{a}}$ & 2003 & 31.9 & 55.3 & 33.3 & 57.0 \\
\hline France $^{\mathrm{a}}$ & 2003 & 33.9 & 52.4 & 47.0 & 45.1 \\
\hline Germany $^{\mathrm{a}}$ & 2003 & 24.1 & 63.0 & 33.9 & 55.2 \\
\hline Italy & 2003 & 17.5 & 74.9 & 24.9 & 70.2 \\
\hline Greece $^{a}$ & 2003 & 46.1 & 47.3 & 54.7 & 39.6 \\
\hline Luxembourg $^{\mathrm{a}}$ & 2003 & 24.5 & 52.7 & 36.9 & 41.7 \\
\hline Portugal $^{\mathrm{a}}$ & 2003 & 28.0 & 54.6 & 32.6 & 60.2 \\
\hline Spain $^{\mathrm{a}}$ & 2003 & 30.3 & 60.8 & 35.7 & 60.3 \\
\hline United Kingdom & 2002 & 26 & 21 & 37.0 & 27.0 \\
\hline \multicolumn{6}{|l|}{ EU-Accession } \\
\hline Bulgaria & 2004 & 34.9 & 62.4 & 34.2 & 63.5 \\
\hline Cyprus & 2002 & 44.7 & 21.8 & 34.9 & 45.5 \\
\hline Czech & 2003 & 13.3 & 69.5 & 18.4 & 66.4 \\
\hline Estonia & 2003 & 70.4 & 8.5 & 22.0 & 61.7 \\
\hline Hungary & 2002 & 12.2 & 83.1 & 18.5 & 73.1 \\
\hline Latvia & 2003 & 26.7 & 57.4 & & 48.9 \\
\hline Poland & 2003 & 25.9 & 63.6 & 28.2 & 58.8 \\
\hline Slovakia & 2002 & 11.6 & 73.9 & 21.2 & 60.1 \\
\hline Slovenia & 2002 & 9.6 & 86.9 & 13.3 & 82.8 \\
\hline
\end{tabular}


The euro is used in invoicing the international trade transactions mainly of European countries. Basically, the euro has replaced European legacy currencies in invoicing euro-area transactions. By contrast, euro invoicing now prevails instead of dollar invoicing mainly in transactions of European Union (E.U.) acceding and accession countries (ECB 2002, 2005). Grassman's Law once more holds, in that euro area countries invoice nearly 60 percent of their exports in euros and only 54 percent of their imports (unweighted average across the countries reported in Table 1). For E.U. acceding and accession countries, the export invoicing is similar, but nearly 65 percent of imported goods are invoiced in euros. Indeed, Goldberg (forthcoming) has questioned whether this share is too high, given the amount of imports that are homogeneous and typically dollar-priced goods and given accession country trade with dollar bloc countries. The role of the euro in invoicing is limited for countries outside of the European Union. In the United States, Japan, Korea, Australia, Malaysia, and Thailand, the euro shares in export and import invoicing are below 10 percent.

These cross-country observations on the currency of invoicing of international trade relate to direction of trade of each country. As a first look, consider the use of dollars in country export invoicing relative to the share of the United States as a direct destination for country exports. This information is shown in Figure 1, which is an updated from Goldberg and Tille (2005). If dollars were used on all country exports to the United States, and not used in other export transactions, the country points indicated in the chart would lie along the 45 degree line. The vehicle currency role of the dollar is reflected in the observation that all countries use dollars more extensively in exports than would be suggested by their partnering in trade with just the United States. 

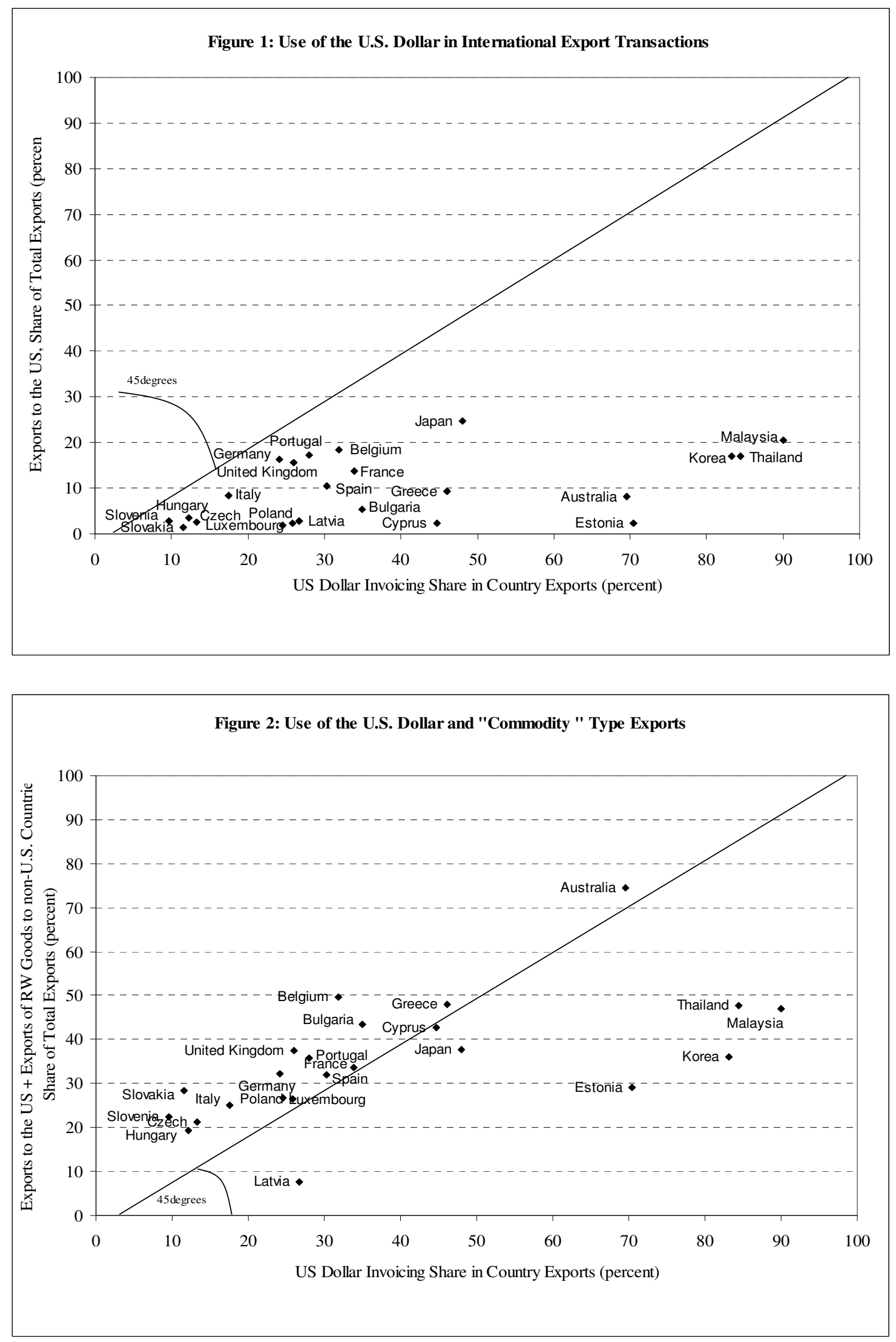
Goldberg and Tille (2005) explored different motives for using the dollar as an invoicing currency. Country exports to the United States and to other dollar bloc countries explain much of the cross-country variation in dollar invoicing. The next, more important, force is the industry composition of country exports. In particular, the extent to which country exports are in homogeneous goods (like commodities) that tend to be reference priced or traded in organized exchanges explain a large part of the remaining gap. This point is illustrated in Figure 2, which is different from Figure 1 only in that vehicle currency use of dollars on homogeneous goods exports also are included to explain total invoicing in dollars. Notice that the observations more tightly wrap around the 45 degree line, with the exception of countries like Malaysia, Thailand and Korea that are typically considered as "dollar bloc" economies.

In addition of the snapshot patterns illustrated in Figures 1 and 2, the available data provide a window into the evolving pattern of dollar use and euro use in invoicing international transactions. Only eleven countries have enough data available to show how currency use has changed since the advent of the euro. All these countries, except Australia, reduced their use of U.S. dollars in export invoicing between 1998 and 2004 (Table 2). The declines were large for countries that have recently acceded or intend to accede to the European Union, for example Bulgaria, Latvia, Lithuania, Poland and Slovakia, reinforcing the observation of Goldberg (forthcoming) and ECB (2005) that institutional issues like exchange rate relationships matter in these cases. Many of the acceding and accession countries have exchange rate regimes that have been (or became) closely aligned with the euro over the past decade. ${ }^{4}$ As observed by the ECB (2005), "countries with clear prospects of being part of the EU, as well as those with hard pegs to the euro, make greater use of the euro in foreign trade even when controlling for actual trade with the euro area". Changes in euro and dollar use in invoicing by these countries are not explained by reduction in country direct trade with the United States.

One of the themes emphasized in the theory of invoice currency selection is that, all else equal, a currency chosen for invoicing will be the one with lowest transaction costs. In recent

\footnotetext{
${ }^{4}$ Goldberg (forthcoming) overviews this information. Bulgaria, Cyprus, Estonia, Hungary, Malta, Slovakia, and Slovenia, tied their currencies either exclusively to the DM or euro or to a basket of currencies dominated by the DM or euro. The Czech Republic pegged their currency to a DM-dominated basket until 1997 and has been floating since them. Poland first had a loose crawling peg to the dollar, and then to the DM and euro, and has been floating since 2000. Slovakia also began with a loose crawling peg to a DM/dollar basket, then began effectively pegging to the euro in 1999. Lithuania was the only country exclusively pegged to the dollar before switching to the euro in 2002 as part of the process of joining the euro zone. Latvia has also been primarily associated with the dollar, pegging to the SDR, a basket in which the dollar has the strongest weight, throughout the period.
} 
decades this has generally been the U.S. dollar, which has the deepest and most liquid markets. The dominance of the dollar has persisted in foreign exchange markets, even since the advent of the euro. Share of dollars and euros in settlement of foreign exchange transactions provided by the Continuous Linked Settlement (CLS) system have been broadly unchanged in recent years. The U.S. dollar accounts for around 90 percent of all daily transactions, and the euro accounts for around 40 percent of transactions (out of a total 200 percent of transactions). While it is an open question on how long the strength of cost advantage associated with transacting in dollars will be retained, bid-ask spreads still favour dollars. ${ }^{5}$

Table 2: Changes in U.S. Dollar Use in Invoicing and in U.S. Share of Country Exports

\begin{tabular}{|c|c|c|c|c|c|c|}
\hline \multirow{2}{*}{ Country } & \multicolumn{3}{|c|}{$\begin{array}{l}\text { U.S. Dollar Share in } \\
\text { Export Invoicing }\end{array}$} & \multicolumn{3}{|c|}{ U.S. Share in Total Country Exports } \\
\hline & 1998 & 2004 & $\begin{array}{c}\text { Change in } \\
\$ \text { Share }\end{array}$ & 1998 & 2004 & $\begin{array}{l}\text { Change in } \\
\text { U.S Share }\end{array}$ \\
\hline Australia & 66.0 & 69.6 & 3.6 & 9.4 & 8.1 & -1.3 \\
\hline Bulgaria & 65.8 & 34.9 & -30.9 & 2.7 & 5.3 & 2.6 \\
\hline Czech & 16.4 & $13.3^{\mathrm{b}}$ & -4.4 & 2.2 & $2.5^{\mathrm{b}}$ & $0.2^{\mathrm{b}}$ \\
\hline Japan & 51.2 & $48.0^{\mathrm{b}}$ & $-3.2^{b}$ & 30.9 & $24.8^{b}$ & $-6.1^{b}$ \\
\hline Korea & 86.3 & 83.2 & -3.1 & 17.4 & 17.0 & -0.4 \\
\hline Latvia & 46.7 & $26.7^{b}$ & -11.5 & 2.9 & $2.9^{b}$ & $0.0^{\mathrm{b}}$ \\
\hline Poland & $36.2^{\mathrm{a}}$ & $25.9^{b}$ & -14.9 & $2.8^{\mathrm{a}}$ & $2.2^{\mathrm{b}}$ & $-0.5^{\mathrm{ab}}$ \\
\hline Slovakia & $28.4^{\mathrm{a}}$ & $11.6^{\mathrm{c}}$ & $-9.4^{\mathrm{ac}}$ & $1.4^{\mathrm{a}}$ & $1.4^{\mathrm{c}}$ & $0.0^{\mathrm{ac}}$ \\
\hline Spain & 40.1 & $30.3^{b}$ & -11.0 & 4.3 & $10.4^{b}$ & $6.1^{b}$ \\
\hline Thailand & 90.6 & $84.4^{b}$ & $-6.2^{b}$ & 22.0 & $17.0^{\mathrm{b}}$ & $-5.0^{\mathrm{b}}$ \\
\hline Czech & 16.4 & $13.3^{\mathrm{b}}$ & -4.4 & 2.2 & $2.5^{\mathrm{b}}$ & $0.2^{\mathrm{b}}$ \\
\hline
\end{tabular}

${ }^{\mathrm{a}}$ Data is for 1999, not $1998 ;{ }^{\mathrm{b}}$ Data is for 2003, not 2004; ${ }^{\mathrm{c}}$ Data is for 2002, not 2004

Source: Author computations using International Financial Statistics, Direction of Trade data. Data sources are provided in Goldberg and Tille (2005), Kamps (2005) and ECB (2005)

\footnotetext{
${ }^{5}$ Hau, Killeen and Moore (2002) find that the euro was a less attractive currency in its early years, compared with the DM, with reduced attractiveness relative to the U.S. dollar.
} 
Overall, the U.S. dollar is likely to maintain its key role as an invoice currency in international transactions. This role is directly tied to the share of the US market as a destination for world production, to the size of dollar bloc countries outside of the United States, to the importance of global trade in commodities and homogeneous goods relative to total trade (which had been declining over time), and to transaction costs that continue to support using the dollar over the euro as a vehicle currency for transactions.

\section{Trade invoicing and exchange-rate pass through}

\section{Empirical evidence on pass through}

While we have overviewed the current state of knowledge on dollar use in invoicing of international trade transactions, a related concept is the degree to which exchange rate changes influence prices of goods imported by countries, the so-called degree of exchange rate pass through. Strictly speaking, invoicing need not be connected to pass through. A European exporter selling goods to the United States can invoice in dollars, i.e. use a dollar price on the contract with the U.S. importer, but can still adjust this price to make up for any fluctuations in the dollar-euro exchange rate. In this case, the invoicing is done in dollars, but exchange rate movements are passed through to the dollar price. ${ }^{6}$

In practice, however, prices are not frequently reset to reflect exchange rate movements. In our example, the European exporter would set a price in dollars for a delivery at a future date and leave this price unchanged even if the dollar-euro exchange rate moves between now and the delivery date. ${ }^{7}$ The European export is then invoiced in dollars, and the price is held constant in dollars. This example represents a case of zero pass-through into U.S. import prices, as the dollar price paid by the U.S. importer is insulated from near-term exchange-rate fluctuations. An alternative scenario would be for the European exporter to fix a price in euros and allow the dollar price of his goods to reflect exchange-rate movements. This case represents complete exchange-rate pass through, as a depreciation of the dollar creates a proportional rise in the

\footnotetext{
${ }^{6}$ Theoretically, Engel (2005) shows the strong parallels between the choice of invoicing when prices are sticky and the optimal degree of exchange rate pass through when prices are fully flexible.

${ }^{7}$ The ECB Monthly Bulletin (November 2005) provides an extensive report on price-setting behaviour in the euro area. The report includes evidence on frequency of price changes across different types of producer and consumer goods, and presents reasons for sluggish price adjustments. Gopinath and Rigobon (2006) document price stickiness evidence in U.S. imports.
} 
dollar price for the imported goods. While invoicing and exchange-rate pass through need not be tied, they are in practice, with the currency of invoicing also being the currency in which prices are held steady. For instance, a European exporter invoicing in dollars not only writes a price in dollars on the contract, but also keeps this price steady in the face of exchange rate movements.

The empirical evidence documented in the previous section, along with the link between invoicing and exchange rate pass through, identifies an asymmetry resulting from the prominent role of the dollar. With U.S. exports and imports both predominantly invoiced in dollars, the prices of U.S. imports are more insulated from exchange rate fluctuations than the prices in local currency terms paid by foreign importers. This asymmetry is clearly present in empirical evidence on exchange-rate pass through into import prices.

The United States is typically found to have low exchange-rate pass through into import prices, with recent estimates ranging from 25 to 40 percent (Olivei 2002, Campa and Goldberg 2005, Marazzi, Sheets, and Vigfusson et al 2005). By contrast, transmission among euro area countries is high, although still incomplete, and different across both industries and countries. Exchange rate changes continue to produce large changes in import prices across euro area countries, on average at 80 percent pass-through rates over the course of a year (Campa, Goldberg, and Gonzalez-Minguez (forthcoming), Ihrig, Marazzi, and Rothenberg 2006). Across the OECD countries more broadly, unweighted average of pass-through elasticities across countries is about 64 percent over one year. Across some countries, there have been statistically significant trends towards lower pass-through rates for manufacturing industries in the period since the 1997 Asia crisis. While, exchange rate pass through into import prices may have broadly declined in recent years, the reasons for such declines and the permanence of lower passthrough rates into industrialized country import prices have not been established.

\section{Invoicing, Import Price Sensitivity and Consumption Price Sensitivity}

A central theme of our manuscript is that the invoicing of international trade is relevant to trade adjustment because of the link between invoicing and the degree of exchange rate transmission into import prices. Import prices influence the consumption prices of traded goods, which interact with demand elasticities to elicit changes in quantities traded and thus real adjustment to exchange rates. It is important to note, however, that import price sensitivity to exchange rates is not identical to consumption price sensitivity. After goods arrive at the docks 
of importing countries, other local services and costs are incurred before the goods reach consumers. These local costs are subsumed under the heading of distribution services and include expenditures on wholesalers, retailers, transportation, and finance and insurance services (Burstein, Neves, and Rebelo 2003; Campa and Goldberg 2006). By adding local content to the imported goods, such expenditures on local currency distribution services partially insulate consumption prices from movements in import prices, and thus from exchange rate movements. A complementary channel for insulation may arise if local distributors adjust their own profit margins to absorb some of the exchange-rate induced changes in good prices at the border (Devereux, Engel, and Tille 2003; Hellerstein 2004). Expenditures on local distribution services are, on average, 32 to 50 percent of the total cost of goods across OECD countries (Campa and Goldberg 2006). The implication is that consumption prices of imported goods may exhibit onethird to half of the sensitivity to exchange rates of import prices at the border. In addition, adjustments of distribution margins can absorb some of the remaining exchange-rate induced

price changes. Overall, the pass through of exchange rates into the consumption prices of imported goods could be less than half of the pass-through into the border prices of those same goods.

Moreover, even this lower retail price sensitivity of imported goods may overstate the extent to which a home currency depreciation raise the price of imports compared with competing home products. If competing domestically-produced goods use imported inputs, home producers' costs rise at the same time that the prices of imports for final consumption rise. While some relative price effects will likely be evident, the percentage change in relative prices at the retail level will be an order of magnitude less than the actual exchange rate fluctuation.

\section{Exchange rate movements and trade adjustment}

Trade adjustment and exchange-rate pass through in symmetric models.

The general principle behind trade balance responsiveness to exchange rate movement is that these movements induce an expenditure-switching effect. Consider the case of trade between the United States and euro-area countries. In a situation of complete exchange-rate pass through in all importing countries, a depreciation of the dollar vis-à-vis the euro makes U.S.-produced goods cheaper to euro-area consumers, boosting the price competitiveness of U.S. firms. 
Consider a movement from one dollar per euro to 1.25 dollars per euro and assume that U.S. exporters charge a set price in dollars, say $\$ 10$, for each unit sold. The price in euros paid by consumers decreases from $10 €$ to $8 €$. If U.S.-made goods are substitutes for euro-area-made goods, European consumers will switch their consumption, increasing their demand for U.S. produced goods and reducing their demand for euro area ones. A similar mechanism would be triggered in the United States, where the dollar price of a euro-area good for which the exporter charges $10 €$ increases from $\$ 10 \$$ to $\$ 12.50$.

In this example of complete and symmetric pass through in prices of both trading partners a dollar depreciation clearly affects the real trade balance by boosting quantities of U.S. exports and reducing quantities of U.S. imports. However, the impact on the nominal trade balance is more complex, because the nominal trade balance also reflects movements in the terms of trade, i.e., the relative price of exports and imports. On the export side, the demand for U.S. goods increases, increasing the quantities shipped by U.S. firms. As the price of each good is typically set in dollars, the nominal dollar value of U.S. exports increases in step with the quantities sold. The situation is more complicated on the import side. Suppose that the exchange rate depreciation is passed through into dollar prices of imported goods. Expenditure-switching leads U.S. consumers to buy fewer European goods, but the price in dollars higher for each unit that is imported. The change in the dollar value of imports is therefore ambiguous: if the quantities imported fall substantially, the U.S. nominal expenditure on imports is reduced. On the other hand, if the quantities bought by U.S. consumers decrease only marginally, the total import bill can increase due to the higher cost of each unit of imported goods.

The price sensitivity of demand is thus a central aspect in trade adjustment (Corsetti and Pesenti 2005, Tille 2001). If demand reacts more than proportionally to price changes, ${ }^{8}$ then a depreciation of the dollar boosts U.S. exports by enough to dwarf the worsening terms-of-trade (i.e. the price of exports relative to the price of imports) and moves the U.S. nominal trade balance toward surplus. If foreign demand is relatively unresponsive to prices, however, the depreciation of the dollar has only a moderate impact on U.S. exports. The adjustment is dominated by worsening terms of trade, so that depreciation of the dollar could even move the nominal trade balance toward higher deficits.

\footnotetext{
${ }^{8}$ This is the case when a 10 percent fall in the relative price of European goods boosts the demand for these goods by more than 10 percent.
} 
The example just presented assumed complete exchange rate pass through into the consumption prices of imports across both trading partners. The previous section, however, showed the restrictive nature of this assumption when we documented the empirical facts of limited transmission of exchange rate movements to prices, especially at short horizons. This evidence has led theoretical analyses to model trade balance adjustment under scenarios where consumer prices are more insulated from exchange rate fluctuations, in some cases making the opposite extreme assumption that exporters set their prices in the currency of their foreign consumers (Betts and Devereux 2000). These local- currency- pricing scenarios have different trade balance effects that are attributed to exchange-rate changes. . The expenditure-switching effect is now absent, as all prices faced by consumers are completely insulated from exchange rate fluctuations. As a result, quantities shipped across borders do not react to exchange rate movements, regardless of the price sensitivity of demands. The impact of the exchange rate comes entirely through income effects. Consider the case of the U.S. exporters and a U.S.dollar depreciation. Under the local-currency-pricing assumption, depreciation of the dollar does not affect the amount of goods shipped to euro area countries, as European consumers do not shift their demand. However, the dollar revenue from each unit sold is higher. This occurs because, with prices set in euros and no change in demand, the exporter receives the same amount of euros as before the depreciation took place. This amount now translates into a larger amount of dollars, increasing the revenue of the exporter in her currency. Similarly, within the United States the dollar price of imports from the euro area would be unchanged. The revenue in euros of European exporters would correspondingly fall. Thus, the depreciation of the dollar would improve the U.S. terms of trade, in sharp contrast to the situation under complete exchange- rate pass through considered above. The opposite happens in the euro area.

The depreciation of the dollar in the case of local- currency- pricing among trade partners unambiguously leads to a nominal trade surplus for the United States. This result entirely reflects the improvement of the U.S. terms of trade, as the real quantities of goods traded are unchanged. In normative terms, the gain for the United States comes at the expense of the rest of the world, where imports are not any cheaper and the revenue from sales in the United States falls in their local currency units. Finally, as we have discussed in our presentation of the empirical evidence on pass through, and as Obstfeld and Rogoff (2000) argue, theoretical models of adjustment need to recognize the distinction between exchange-rate pass through into import 
prices, i.e. prices at the dock, and into consumer prices. Distinguishing between prices at different stages of the production chain allows for exchange rate movements to generate a substantial switching effect, while having little impact on consumer prices. Obstfeld (2001) argues that the allocation between domestic and imported goods is not limited to consumers, but extends to firms that can substitute imported inputs for domestic ones. Exchange rate movements induce firms to switch between different inputs, as long as these movements are transmitted to intermediate prices. This action by firms is consistent with the absence of switching from consumers who face prices that are insulated. The effective degree of switching induced by exchange rate movements is therefore understated by the limited impact on consumer prices.

\section{Trade adjustment in an asymmetric world}

The theoretical connection between exchange rate pass through and the channels of trade adjustment has been explored mostly in symmetric models, where the degree of exchange-rate pass through into import prices and consumption prices is the same across trading partners. The empirical evidence presented above, however, emphasizes an asymmetric world with a prominent role of the dollar as an invoicing currency. This invoicing role implies that exchangerate pass through to U.S. import prices is limited, while the pass through into the import prices of other countries around the world is substantially higher. In practice, U.S. exports and the exports of dollar-bloc countries are primarily invoiced in dollars. A dollar depreciation keeps relatively steadily the prices in the United States, but affects the euro prices faced by European consumers on exports from other countries that had been dollar priced. Since asymmetric pass-through is the appropriate scenario for exploring current account imbalances that involve the United States, we focus exclusively on this theme in this section.

\section{Links between the U.S. and the rest of the world}

Under asymmetric pass through, and with prices fixed in dollars, a depreciation of the dollar leads to expenditure switching in the foreign market towards U.S. goods and increases the quantities of goods exported by the United States. The situation is different for U.S. imports, which follow the scenario in which exchange-rate pass through into U.S. import prices is very low. With prices largely unchanged in dollar terms, U.S. consumers do not reallocate their 
purchases, leaving real quantities imported unchanged. The revenue of European exporters measured in euros decreases, as the set dollar revenue now translates into a smaller amount of euros.

This pattern of trade adjustment under asymmetric exchange-rate pass through lies between the two polar cases previously discussed, with effects on the real trade balance of the United States driven by higher U.S. exports without associated movements in U.S. imports. The prices of both U.S. exports and imports are unchanged in dollar terms, so the terms of trade are insulated from the exchange rate. The United States, then, does not suffer from any terms-oftrade worsening, as it would under symmetric and complete pass through, but it does not benefit from any improvement either, as it would under the case where all trading partners pursue a local-currency-pricing strategy, where there is zero pass through into the import prices in all trading partners.

These mechanisms for trade balance adjustment carry over to detailed scenario analyses and models. Simulation exercises recently performed at the Federal Reserve Board by Gust and Sheets (2006) focus on the patterns of trade adjustment under alternative structures of pass through using a dynamic general equilibrium model of transactions between two countries. A depreciation of the dollar leads to a nominal trade surplus (relative to an initial condition of balanced trade) in all scenarios, with the pace of adjustment depending on the structure of pass through. In the absence of any pass through into import prices across countries, the nominal trade balance of the United States immediately moves into surplus and remains steady as prices and policies adjust. Under complete exchange-rate pass through into import prices across countries, the nominal trade balance of the United States initially moves into deficit due to frictions in real trade flow adjustment, but then quickly moves into surplus, eventually stabilizing with a larger nominal trade surplus than in the scenarios of local-currency pricing (i.e. the absence of pass through in both countries trading). The pattern under asymmetric pass through, with all trade flows invoiced in dollars, falls in between, with a moderate trade surplus gradually building up for the United States.

Within the full simulation exercise of Gust and Sheets (2006), a 10 percent depreciation of the U.S. dollar increases the trade surplus in dollar terms by about 1 percentage point of GDP at 
an horizon of 6 quarters. ${ }^{9}$ While this effect is similar in all scenarios for the authors' assumed model parameters, the underlying pattern of adjustment across countries varies substantially with the assumptions made about pass-through of exchange rates into traded-goods prices. When pass through is complete into the import prices of all trade partners (a producer-currency-pricing scenario), the nominal trade balance adjustment is driven by movement in real quantities exported and imported, with a partial offset through the terms-of-trade. The dollar depreciation leads to substantial expenditure switching, with U.S. export quantities increasing by 9 percent in real terms and import quantities contracting by a similar magnitude. This large trade surplus in real terms is substantially offset by a 10 percent worsening of the terms-of-trade, reflecting higher import prices.

In the scenario with low rates of exchange-rate pass through into the import prices of both countries, the trade-balance adjustment takes place mostly through improved terms of trade. As local-currency import prices are shielded from exchange rate movements, the only effect of the depreciation is a small increase in real exports. The depreciation generates an income effect by raising the revenue-per-unit of exporters by 6.5 percent measured in their own currency. The rise in revenue constitutes an improvement in the terms of trade, creating a trade surplus in dollar terms.

The adjustment in the more realistic scenario of asymmetric pass through is a combination of both cases. The depreciation generates substantial expenditure switching on the export side, with real exports increasing 9 percent, but without any such effect operating on the import side. Real imports contract very little for the United States, as in the case of limited pass through. While the depreciation generates only a moderate trade surplus in real terms, it translates nearly one-for-one into a surplus in dollar terms, as there is only a moderate worsening of the terms of trade.

\section{Links between non-U.S. countries}

In addition to affecting the trade adjustment between the U.S. and the rest of the world, the prominent role of the dollar also affects trade transactions among countries other than the United

\footnotetext{
${ }^{9}$ Our example uses the impulses responses of Gust and Sheets (2006) at 6 quarters. As the dollar depreciation is slightly different across the scenarios, and above 10 percent, we re-scale all the values to correspond to a 10 percent depreciation. The scenarios of Gust and Sheets (2006) are more complex than our simple discussion, since they reflect both an exchange rate depreciation and the associated reaction of monetary policy to inflationary pressures.
} 
States (Goldberg and Tille 2006). For illustration purposes, suppose that there are two non-U.S. "countries" that trade only with each other. Suppose we refer to these "countries" as Asia and Latin America. If none of their bilateral trade is invoiced in dollars, their bilateral trade balance is driven by their bilateral exchange rate, following the mechanisms described in the symmetric models.

The situation differs substantially if all trade between Asia and Latin America is invoiced in U.S. dollars, consistent with the dollar's vehicle currency role. In this case, the bilateral terms of trade are shielded from exchange rate movements. With all trade prices set in the same currency (the dollar), any exchange rate movement affects export and import prices equally, and leaves the relative price unchanged. With these constant terms of trade, any trade adjustment comes through movements in real trade flows between the two countries. If the dollar depreciates against both the Asian and Latin American currencies, imports in both countries are cheaper in local currency terms, leading consumers in each country to shift expenditure towards imported goods. With equal depreciation against both currencies, exports and imports increase to the same extent with little impact on the trade balance. ${ }^{10}$ The international role of the dollar causes the exchange rate between the dollar and foreign currencies to affect even that portion of other countries' trade that does not directly involve the U.S. as a partner, a novel channel of interdependence.

The prominent role of the dollar also influences the results of bilateral exchange rate movements between the dollar and the currencies of both hypothetical countries of our example, "Asia" and "Latin America". Consider a depreciation of the dollar against the Asian currency only, with no change in the exchange rate between the dollar and the Latin American currency. By implication, the Asian currency appreciates against both the dollar and the Latin American currency. These exchange rate movements make imports cheaper in Asia, leading to an expenditure switching towards Latin American goods. The price of Asian goods in Latin America remains unchanged, hence no expenditure switching. The dollar depreciation asymmetrically affects trade flows, boosting Asian imports with no effect on exports, thereby creating a trade deficit for Asia.

\footnotetext{
${ }^{10}$ If trade is initially balanced between the two countries, higher exports and import exactly offset each other. If, on the other hand, one country starts with a trade surplus, an equal increase in exports and imports in percentage terms boosts the surplus.
} 
The pattern of Asia-Latin America adjustment is a mix of the symmetric cases of full and zero exchange-rate pass through. Assume a depreciation of the dollar against the Asian currency, with no change against the Latin American currency. With all trade of each country invoiced in dollars, Asia runs a larger nominal trade deficit than under full pass through, since it does not benefit from any terms-of-trade improvement and a smaller nominal trade deficit than under zero pass through, since it suffers no worsening either.

\section{Ownership of the distribution sector}

The large role of the distribution sector also changes how exchange rate movements affect the trade balance. We previously noted that local expenditure on distribution services leads exchange-rate pass through into the final consumption prices of goods to be lower than the exchange-rate pass through into import prices measured at the border. Another issue for trade balance adjustment pertains to the ownership of this distribution sector. When the dollar is the primary invoicing currency, a dollar depreciation reduces the profits of foreign exporters. With prices fixed in dollars in the United States, the revenue in euros of a European producer is reduced. The presence of a distribution sector affects how this change of revenue is allocated along the production chain. For instance, suppose that dollar import prices react somewhat to the depreciation, as is the case under the partial exchange rate pass through observed for the United States. If there is active adjustment of distribution margins, some of the expenditure-switching from a dollar depreciation is reduced with some of the revenue reduction borne by the distribution sector in the United States. If retailers are subsidiaries of the European exporters, such as dealerships for imported cars, the reduction in revenue is still borne entirely by European firms. On the other hand, if the distribution sector is made up of U.S. firms, the reduction in revenue is now split between the two countries.

The relevance of the distribution sector is illustrated through the scenarios discussed above, focusing on the case where all trade is invoiced in dollars. Consider an extreme case where there is full exchange rate pass through to import prices in the U.S., but no pass through to consumer

prices. As U.S. consumers face constant prices, a depreciation of the dollar does not lead to any consumption switching, and the real imports from Europe are unchanged. The only impact of the weaker dollar is to reduce the profits of the U.S. distribution sector, where firms are caught between higher import prices and constant consumer prices. If the distributors are European 
firms, the depreciation reduces the revenue of European firms as measured in euros, which is the worsening of the European terms of trade discussed above.

Empirical evidence, however, suggests that the intermediaries in the U.S. distribution sector are primarily U.S.-owned (Tille 2000). In this extreme example, European exporters are insulated from the depreciation of the dollar: the quantities shipped to the U.S. are unchanged, and the full pass through to import prices implies that they receive an unchanged price in euros. The depreciation of the dollar is then beneficial to Europe, as exporters revenue is unchanged and European consumers benefit from cheaper U.S. goods. The cost of the depreciation falls entirely on the U.S. distribution firms which suffer from lower margins.

\section{Policy implications and conclusions}

The role of the dollar as a key invoicing currency in international trade transactions is related to the presence of the U.S. as a main producer and destination market for goods, the importance of commodities and other homogeneous goods in world trade, the number of countries that de facto or de jure tie their exchange rates and pricing activity to the dollar, and, to a lesser extent, the pattern of covariances among production costs, destination market demand conditions, and exchange rates. Transaction costs in foreign exchange markets also play a role. In recent decades, the share of the U.S. in world imports has been fairly stable (cyclically adjusted) at nearly 15 percent, the share of homogenous goods in world trade has been declining, and the foreign exchange market cost advantage of the dollar has been largely maintained. The evidence we have surveyed shows that while the euro has increased its role as an international currency, this pattern is largely contained to countries within the European Union and has otherwise not been at the expense of invoicing in U.S. dollars.

This continuing international role of the dollar and related evidence on exchange rate pass through into prices affect the pattern of international trade adjustment. We have argued that a depreciation of the dollar, for example, would have asymmetric effects on flows between the U.S. and its trading partners. With low exchange-rate pass through into U.S. import prices, and high pass-through into the local prices of countries consuming U.S. exports, the impact of dollar depreciation on real trade flows is dominated by an adjustment in U.S. export quantities, which increase as U.S. goods become cheaper in the rest of the world. Real U.S. imports are less 
affected because U.S. prices are more insulated from exchange rate movements since pass through is low and dollar invoicing is high. In terms of prices, the effects on the U.S. terms of trade are limited: U.S. exporters earn the same amount of dollars for each unit shipped abroad, and U.S. consumers are not burdened with much more expensive imports.

The use of the dollar as an invoicing currency also affects the trade adjustment between countries, even beyond the effects of direct trade links with the United States. If the trade transactions between other countries are fully invoiced in dollars, the bilateral terms of trade are insulated from exchange rate movements and the adjustment comes entirely through real trade flows. A depreciation of the U.S. dollar boosts all trade flows between these countries, with little impact on the net trade balance. In addition, a depreciation of one of the countries' currency against all others, including the dollar, can have contractionary effects on that country. The terms of trade are unchanged, export quantities are unchanged, and import quantities decline. While the country runs a trade surplus, this arises from a reduction in imports instead of an export boom. If two countries have different patterns of currency invoice selection on competing goods, a depreciation of the U.S. dollar against both currencies leads to relative improvements in the country using dollars more extensively.

The robustness of asymmetric pass-through is an open question. Low exchange-rate pass through into U.S. import prices has as a counterpart high absorption of exchange rate movements in foreign profit margins. This absorption of exchange rate movements into foreign margins may not be a phenomenon that can be maintained under large and persistent exchange rate movements. Pass through into the United States import prices may rise if the dollar falls far enough to cause the export price to the United States to fall below marginal cost. As long as foreign exporters sell in the US above marginal cost they can stabilize dollar prices. However a large enough dollar depreciation would push U.S. sales price below marginal cost. Over longer run horizons, United States and foreign prices could share the nominal and read adjustments associated with large terms-of-trade movements.

Twenty-five years after Kenen and Pack (1980), we confirm two critical issues in balanceof-payments adjustment: the size and speed of the response of domestic prices to a change in the exchange rate, and the adjustment of trade quantities to these relative price changes. We have argued that the important role of the dollar as an invoicing currency on international transactions and the evidence that exchange rate pass-through is asymmetric across countries both have 
strong bearing on the pattern of trade adjustments that could arise following nominal exchange rate movements. The trade adjustments are relevant for countries that are direct counterparties in trade with the United States, but also for those countries that use dollars as invoicing currencies in their transactions with third parties.

\section{References}

Bacchetta, Philippe and Eric van Wincoop (2005), A Theory of the Currency Denomination of International Trade, Journal of International Economics 67(2), pp. 295-319.

Betts, Caroline, and Michael Devereux (2000), Exchange Rate Dynamics in a Model of Pricing to Market, Journal of International Economics 50 (1), pp. 215-244.

Burstein, Ariel, Joao Neves and Sergio Rebelo (2003), "Distribution Costs and Real Exchange Rate Dynamics during Exchange-Rate-Based Stabilizations" Journal of Monetary Economics, v. 50, pp. 1189-1214.

Campa, Jose and Linda Goldberg (2006), Distribution Margins, Imported Inputs, and the Sensitivity of the CPI to Exchange Rates, National Bureau of Economic Research Working Paper no. 12121 (March).

Campa, Jose and Goldberg, Linda (2005), "Exchange Rate Pass-Through into Import Prices." Review of Economics and Statistics, (November) 87 (4): 679-690.

Campa, Jose, Linda Goldberg, and Jose Gonzalez-Minguez. "Exchange-Rate Pass-Through to Import Prices in the Euro Area", The External Dimension of the Euro Area, ed. Robert Anderton and Filippo di Mauro, Forthcoming (Cambridge University Press).

Corsetti, Giancarlo, Luca Dedola, and Sylvain Leduc (2005). "DSGE Models of High ExchangeRate Volatility and Low Pass-Through," International Finance Discussion Papers Board of Governors of the Federal Reserve System no 845 (November).

Corsetti, Giancarlo, and Paolo Pesenti (2005), The Simple Geometry of Transmission and Stabilization in Closed and Open Economies, mimeo, Federal Reserve Bank of New York.

Devereux, Michael, Charles Engel, and Peter Storegaard (2004), Endogenous Exchange Rate Pass-Through when Nominal Prices are set in Advance, Journal of International Economics, 63(2), pp. 263-291.

Devereux, Michael, Charles Engel, and Cédric Tille (2003), Exchange Rate Pass-Through and the Welfare Effects of the Euro, International Economic Review, vol. 44, pp. 223-252. 
Devereux, Michael, and Shi, Shouyong (2005), Vehicle currency, mimeo, University of British Columbia.

Donnenfeld, Shabtai and Alfred Haug (2003), "Currency Invoicing in International Trade: An Empirical Investigation." Review of International Economics, 11, pp. 332-345.

Donnenfeld, Shabtai and Alfred Haug (2002), "Currency Invoicing in U.S. Imports." Mimeo, York University Department of Economics.

Engel, Charles (2005), Equivalence Results for Optimal Pass-Through, Optimal Indexing to Exchange Rates, and Optimal Choice of Currency for Export Pricing, National Bureau of Economic Research Working Paper No. 11209.

European Central Bank (2005, 2002), Review of the International Role of the Euro, December.

Feldstein, Martin (2006), “The Dollar at Home - and Abroad”, The Wall Street Journal, April 28, 2006. http://www.nber.org/feldstein/wsj042806.html

Friberg, Richard (1998), "In which Currency Should Exporters Set their Prices?" Journal of International Economics, 45(1), pp. 59-76.

Gagnon, Joseph (2003), "The Effect of Exchange Rates on Prices, Wages, and Profits: A Case Study of the United Kingdom in the 1990s" Board of Governors of the Federal Reserve System International Finance Discussion Papers no. 772 (August).

Giovannini, Alberto (1988), Exchange Rates and Traded Goods Prices, Journal of International Economics, 24, pp.45-68.

Goldberg, Linda. "Trade Invoicing in the accession countries: Are they suited to the euro?" International Seminar on Macroeconomics, ed. Jeffrey Frankel Forthcoming (NBER and University of Chicago Press).

Goldberg, Linda and Cédric Tille (2006), "Exchange Rate Transmission with a Vehicle Currency", manuscript, Federal Reserve Bank of New York

Goldberg, Linda, and Cédric Tille (2005), "Vehicle Currency Use in International Trade", NBER Working Paper 11127 February 2005.

Gopinath, Gita, and Roberto Rigobon (2006), "Sticky Borders", National Bureau of Economic Research working paper 12095.

Grassman, Sven (1973), A Fundamental Symmetry in International Payments, Journal of International Economics, 3, pp. 105-16. 
Gust, Christopher and Nathan Sheets (2006), “The Adjustment of Global External Imbalances: Does Partial Exchange Rate Pass-Through to Trade Prices Matter?" International Finance Discussion Papers number 850.

Hartmann, Philipp (1998), "The Currency Denomination of World Trade after European Monetary Union." Journal of the Japanese and International Economies, 12, pp. 424-54.

Hau, Harald, William Killeen and Michael Moore (2002), "How has the Euro changed the Foreign Exchange Market? Economic Policy, Vol. 17, pp. 149-192.

Hellerstein, Rebecca (2004), "Who Bears the Cost of a Change in the Exchange Rate? The Case of Imported Beer”, Staff Reports no. 179 (February), Federal Reserve Bank of New York.

Ihrig, Jane E., Mario Marazzi, and Alexander Rothenberg (2006), "Exchange Rate Pass-Through in the G-7 Countries", International Finance Discussion Papers number 851.

Kamps, Annette (2005), "The Determinants of Currency Invoicing in International Trade", manuscript, Institute for World Economics.

Kenen, Peter and Clare Pack (1980), Exchange Rates, Domestic Prices, and the Adjustment Process, Group of 30 Occasional Papers 1.

Kenen, Peter (1983), The Role of the Dollar as an International Currency, Group of 30 Occasional Papers 13.

Krugman, Paul (1980), "Vehicle Currencies and the Stucture of International Exchange," Journal of Money, Credit and Banking, vol. 12 pp. 513-526.

Marazzi, Mario, Nathan Sheets, Robert Vigfusson et al. (2005), “Exchange Rate Pass-through to U.S. Import Prices: Some New Evidence," International Finance Discussion Paper No. 833, April.

McKinnon, Ronald (1979), Money in International Exchange: The Convertible Currency System, Oxford University Press, Oxford.

Obstfeld, Maurice (2001), International Macroeconomics: Beyond the Mundell-Fleming Model, International Monetary Fund Staff Paper 47.

Obstfeld, Maurice, and Kenneth Rogoff (2000), New Directions for Stochastic Open Economy Models, Journal of International Economics, 50, pp. 117-153.

Oi, Hiroyuki, Akira Otani, and Toyoichiro Shirota (2004), "The Choice of Invoice Currency in International Trade: Implications for the Internationalization of the Yen." Monetary and Economic Studies, pp.27-63. 
Olivei, Giovanni P. (2002), "Exchange Rates and the Prices of Manufacturing Products Imported into the United States", New England Economic Review (1st quarter) pp. 3-18.

Portes, Richard and Helene Rey (1998), "The Emergence of the Euro as an International Currency." Economic Policy, vol. 13 vo. 26, pp.305-343.

Rey, Hélène (2001), International Trade and Currency Exchange, Review of Economic Studies, 68, pp. 443-464.

Swoboda, Alexander (1969), "Vehicle Currencies and the Foreign Exchange Market: the Case of the Dollar", The International Market for Foreign Exchange, ed. Robert Z. Aliber, Praeger Special Studies in International Economics and Development, (Frederick A. Praeger, Publishers, New York).

Swoboda, Alexander (1968), “The Euro-Dollar Market: An Interpretation”, Essays in International Finance 64, International Finance Section, Princeton University.

The Conference Board (2005). "Do Exchange Rates Matter? A Global Survey of CEOs and CFOs on Exchange Rates" written in cooperation with the Group of Thirty. The Conference Board Research Report R-1349-04-RR.

Tille, Cédric (2001), The Role of Consumption Substitutability in the International Transmission of Shocks Journal of International Economics, April 2001, vol. 53, pp. 421-444.

Tille, Cédric (2000), Beggar-Thy-Neighbor' or 'Beggar-Thyself'? The Income Effect of Exchange Rate Fluctuations", Federal Reserve Bank of New York Staff Report 112.

Wilander, Fredrik (2006), "An Empirical Analysis of the Currency Denomination in International Trade", mimeo, Stockholm School of Economics. 